\title{
Experiments on the influence of Chaoborus brasiliensis Theobald, 1901 (Diptera: Chaoboridae) on the diel vertical migration of microcrustaceans from Lake Monte Alegre, Brazil
}

\author{
Minto, WJ., Arcifa, MS. * and Perticarrari, A. \\ Departamento de Biologia - FFCLRP, Universidade de São Paulo - USP, \\ Av. Bandeirantes, 3900, CEP 14040-901, Ribeirão Preto, SP, Brazil \\ *e-mail: marcifa@usp.br \\ Received July 23, 2008 - Accepted October 8, 2008 - Distributed February 28, 2010
}

(With 7 figures)

\begin{abstract}
The aim of this work was to evaluate whether diel vertical migration of microcrustaceans from Lake Monte Alegre is related to invertebrate predators, namely larvae of Chaoborus brasiliensis. The hypothesis tested in the experiments was that the migratory behaviour of prey would depend on physical contact with Chaoborus brasiliensis larvae or with kairomones released by them.

Two experiments were undertaken in the laboratory, with two treatments and three replicates each. Experiments were carried out in acrylic cylinders $1.5 \mathrm{~m}$ high and $0.20 \mathrm{~m}$ in diameter. Treatments in Experiment I were: A) predator and kairomones present and B) predator and kairomones present, but predator isolated in net tube inside the cylinder, having no physical contact with prey. Treatments in Experiment II were: A) predator and kairomones absent and B) the same as in experiment I.

Physical and chemical factors (temperature, dissolved oxygen, $\mathrm{pH}$, electrical conductivity) and food (algae) did not influence vertical distribution of prey, as they were almost homogeneously distributed in the water column in both experiments; food concentrations were not limiting. Adult copepods (Tropocyclops prasinus meridionalis and Thermocyclops decipiens) showed reverse migration in the treatment B of both experiments; the cladoceran Daphnia gessneri migrated nocturnally in the treatment A of the Experiment I; vertical migration was undetectable for copepodites, as well as for Chaoborus larvae.

The experiments indicated that Daphnia responded to physical contact with Chaoborus larvae but not to kairomones alone. Adult copepods seemed to be more sensitive to kairomones.
\end{abstract}

Keywords: diel vertical migration, Daphnia gessneri, Tropocyclops prasinus meridionalis, Thermocyclops decipiens, larvae of Chaoborus brasiliensis.

\section{Experimentos sobre a influência de Chaoborus brasiliensis (Diptera: Chaoboridae) sobre a migração vertical de microcrustáceos do Lago Monte Alegre, Brasil}

\footnotetext{
Resumo

O objetivo deste trabalho foi avaliar se a migração vertical dos microcrustáceos do Lago Monte Alegre é relacionada aos predadores invertebrados, nomeadamente larvas de Chaoborus brasiliensis. A hipótese testada no experimento foi a de que o comportamento migratório da presa seria dependente do contato físico com as larvas de Chaoborus ou dos "kairomones" liberados por elas.

Dois experimentos foram realizados no laboratório, com dois tratamentos e três réplicas cada. Os experimentos foram feitos dentro de cilindros de acrílico de 1,5 $\mathrm{m}$ de altura e $0,20 \mathrm{~m}$ de diâmetro. Os tratamentos do Experimento I foram: A) predador e "kairomones" presentes e B) predador e "kairomones" presentes, mas o predador isolado em tubos de rede dentro do cilindro, não tendo contato físico com a presa. Os tratamentos do Experimento II foram: A) predador e "kairomones" ausentes e B) igual ao Experimento I.

Fatores físicos e químicos (temperatura, oxigênio dissolvido, $\mathrm{pH}$, condutividade elétrica) e alimento (algas) não influenciaram a distribuição vertical das presas, pois eles estavam quase homogeneamente distribuídos na coluna d'água em ambos os experimentos; as concentrações de alimento não foram limitantes. Copépodos adultos (Tropocyclops prasinus meridionalis e Thermocyclops decipiens) realizaram migração reversa no tratamento B dos dois experimentos; o cladócero Daphnia gessneri migrou de modo noturno no tratamento A do Experimento I; migração vertical não foi detectada para copepoditos, bem como para larvas de Chaoborus.
} 
Os experimentos indicaram que Daphnia respondeu ao contato físico com as larvas de Chaoborus e não aos "kairomones". Copépodos adultos foram aparentemente mais sensíveis aos "kairomones".

Palavras-chave: migração vertical, Daphnia gessneri, Tropocyclops prasinus meridionalis, Thermocyclops decipiens, larvas de Chaoborus brasiliensis.

\section{Introduction}

Diel vertical migration (DVM) is a phenomenon displayed by several organisms inhabiting freshwater bodies and oceans. Nocturnal migration is the most common migratory pattern, animals ascending to surface layers at night, descending during the day (Hutchinson, 1967). Another patterns, rarer, are the reverse migration, which is contrary to the nocturnal one, and the twilight migration, with two surface peaks, at sunset and dawn.

The role of light as the main cause of DVM (Hutchinson, 1967; Ringelberg, 1980; 1991a) has been widely accepted, but several hypotheses have been raised on its adaptive value. From the seventies onwards, the avoidance of predation by fish and invertebrates has reached the status of the main ultimate cause of DVM (Zaret and Suffern, 1976; Wright et al., 1980; Stich and Lampert, 1981; Ohman et al. 1983; Lampert and Taylor, 1985; Gliwicz, 1986; Ohman, 1990). Nocturnal migration might be the prey response to visual predation by fish and reverse migration the response to invertebrate predation.

Studies in the field (Dini and Carpenter, 1988; 1991; Ringelberg et al., 1991) and laboratory (Dawidowicz et al., 1990; Tjossem, 1990; Loose, 1993) evidenced that prey DVM was reduced or absent in a predator-free environment or conspicuous in the presence of predators. Quick shifts of prey migratory behaviour in the absence and presence of predators (Bollens and Frost, 1991; Neill, 1990) indicated a phenotipic response possibly related to substances excreted by predators, known as kairomones. There is evidence that prey is able to detect kairomones and, therefore, the presence of predators (Neill, 1990; Ringelberg, 1991b, c; Larsson and Dodson, 1993; Loose, 1993; Loose et al., 1993; von Elert and Pohnert, 2000). Kairomones, whose chemical structure is unknown (Lass and Spaak, 2003), are soluble in water, non-volatile, with low molecular weight, provoking behavioural and physiological reactions on the receptor, being favourable to prey but not to predators. DVM displacements, triggered by light, with organisms reacting phototactically to different intensities, are magnified by chemical signs produced by predators. These signs motivate zooplankton migration, while the relative changes in light intensity control the onset and extension of DVM (Ringelberg, 1991c; 1993). Kairomones can also be considered a proximate cause of migration and escape from predation might be the ultimate cause.

Predators in Lake Monte Alegre are Chaoborus brasiliensis Theobald, 1901 larvae (Arcifa, 2000; Castilho-Noll and Arcifa, 2007a; 2007b), the water mite
Krendowskia sp. (Cassano et al., 2002) and adults of the fish Tilapia rendalli (Arcifa and Meschiatti, 1996). Tilapias are mainly phytoplanktivores, catching mostly cladocerans in the water current resulting from pump filter feeding. Moreover, most fish larvae and juveniles do not prey on zooplankton (Meschiatti and Arcifa, 2002), and both adult and young fishes are mainly littoral dwellers (Arcifa and Meschiatti, 1993). Therefore, Chaoborus larvae, and to a lesser extent water mites, are the main predators of zooplankton in the open area of the lake.

Two studies on DVM of microcrustaceans, in 1985/86 and 1999, revealed that after the disappearance of the favorite cladoceran prey, Bosmina tubicen, Chaoborus larvae exerted a higher predation pressure on copepods; apparently, as a consequence, there has been a change of a weak twilight pattern, in 1985/86, to a reverse one, in 1999 (Perticarrari et al., 2004). Aggregates of Daphnia gessneri Herbst, 1967 in the lake were interpreted as a strategy to cope with invertebrate predation (Perticarrari et al., 2003).

The objectives of the experiments in the laboratory presented here were to test the influence of Chaoborus larvae on the diel vertical migration of the cladoceran Daphnia gessneri and of the copepods Tropocyclops prasinus meridionalis (Kiefer, 1931) and Thermocyclops decipiens (Kiefer, 1929). The experiments dealt with these organisms, because they were the only planktonic microcrustaceans abundant enough in the lake at the time to insure the analyses.

The experiments were designed to investigate the hypotheses that prey DVM might be induced by physical contact with the predator or substances produced by the larvae could be sufficient to influence the vertical displacement of the microcrustaceans.

\section{Study area}

Lake Monte Alegre $\left(21^{\circ} 11^{\prime} \mathrm{S}\right.$ and $\left.47^{\circ} 43^{\prime} \mathrm{W}\right)$ is a small (area $=7$ ha), shallow $(\mathrm{Z}$ max. $=5 \mathrm{~m}$, Mean $\mathrm{z}=2.9 \mathrm{~m}$ ), warm discontinuous polymictic reservoir (Arcifa et al., 1990), located on the campus of the University of São Paulo, in Ribeirão Preto, State of São Paulo, southeastern Brazil. The lake was formed in 1942 by the damming of Laureano Creek, which belongs to the River Pardo basin. The region has a tropical climate, with a marked cool-dry season (May-September) and a warm-wet season (October-April). Because the outlet is superficial and the dam is not manipulated, the impoundment functions as a small lake, with a retention time of about 45 days at the end of the wet season. Stratification 
periods, particularly during summer, can lead to oxygen depletion in the narrow hypolimnion (Arcifa et al., 1990).

The lake is eutrophic, and has sporadic small cyanobacteria blooms. Eight planktonic cladoceran species were recorded in four periods (1985/86, 1988/89, 1998/99, and 2001/02) (Arcifa et al., 1992; 1998; Fileto, 2001; Bunioto, 2003): Bosmina tubicen, Ceriodaphnia cornuta, C. richardi, Daphnia ambigua, D. gessneri, Diaphanosoma birgei, Moina micrura, and M. minuta; and two cyclopoid copepod species: Thermocyclops decipiens and Tropocyclops prasinus meridionalis.

\section{Material and Methods}

Two experiments were carried out in the laboratory in June 2004, for one week each, including the acclimation period of the organisms. Two treatments were made for each experiment, with three replicates each. Small plastic taps were added at the following depths $(0.30$, $0.80,1.30 \mathrm{~m}$ ) (Figure 1) to transparent acrylic cylinders, $1.5 \mathrm{~m}$ high and $0.2 \mathrm{~m}$ in diameter, holding $46 \mathrm{~L}$. Pieces of cloth, ochre and black coloured, covered the lower external parts of the cylinders, to simulate the light attenuation in the water column of the lake. Two extra cylinders, one for each treatment, were used as reserve for water replacement of the cylinders after water samplings were taken through the taps.

Cylinders of the experiments were positioned inside a room with controlled temperature $\left(22-24{ }^{\circ} \mathrm{C}\right)$, lit by 8 fluorescent lamps $(12 \mathrm{~V}, 32 \mathrm{~W})$ hanging from the ceiling, covered by translucent paper, functioning as a screen (Figure1) for providing a diffuse light. Light was automatically switched off at night by a dimer. In all treatments, $0.2 \mathrm{mg} \mathrm{C.L^{-1 }}$ of the cloroficean Scenedesmus spinosus (Chodat, 1913) was added once a day, to prevent any influence of food limitation on the distribution of microcrustaceans (Johnsen and Jakobsen, 1987). Cylinders were distributed in a systematic arrangement for preventing pseudoreplication.

Water was taken from the lake with a pump delivering $30 \mathrm{~L} /$ minute. For increasing the density of microcrustaceans in the experiments, vertical towns were made in the lake with a $60 \mu \mathrm{m}$ meshed net, zooplankton being concentrated in $8 \mathrm{~L}$ ( $1 \mathrm{~L} /$ cylinder). For those treatments without predator, the water was filtered through nets of 500 and $140 \mu \mathrm{m}$, for retaining Chaoborus larvae.

Experiment I tested the effect of physical contact between prey and predator (treatment A), and contact between prey and kairomones without physical contact with predators (treatment B). Treatments were: 1 . Treatment A: total zooplankton + Chaoborus larvae $(\mathrm{P}+\mathrm{K}+)$; a small amount of sand was placed at the bottom of the cylinders for simulating field conditions for the larvae; in this treatment, prey was in contact with predator and kairomones; 2. Treatment B: total zooplankton inside the cylinders + Chaoborus separated in net tubes $(\mathrm{P}-\mathrm{K}+)$; a tube made of $60 \mu \mathrm{m}$ meshed net, was introduced into the acrylic cylinders, where larvae were confined together with food; in this treatment prey inside the cylinders were in contact with kairomones but not directly with predators; prey were evaluated in the acrylic cylinder but not inside the net tube of the treatment, due to technical difficulties.

Experiment II tested the effect of the absence of predators and kairomones (treatment A) and the contact between prey and kairomones but not physical contact with predator (treatment B). Treatments were: 1. Treatment A: without predator and kaironomes $(\mathrm{Pa} \mathrm{K}-)$; cylinders were filled with lake water with zooplankton but without predators; 2. Treatment B: like the treatment B of Experiment I $(\mathrm{P}-\mathrm{K}+)$, described above.

For filling the cylinders without predators (treatment B of Experiments I and II and treatment A of Experiment II), water was filtered through a plastic cylinder containing two nets (500 and $140 \mu \mathrm{m})$ for retaining predators. The larvae retained on the nets were sucked by a pipette and introduced into the net tubes of treatment B. Then, the nets were gently washed for rescuing zooplankton, which was introduced into the cylinders. Visual observations of the cylinders, with a magnifying glass, showed that both predator and prey were not been injured by manipulation.

Organisms were acclimated for 48 and 72 hours, before starting the Experiments I and II, respectively. According to Loose (1993) 72 hours was the time required for kairomones to degrade, a necessary requisite for treatment A of Experiment II.

Water samples $(2 \mathrm{~L})$ were taken from the cylinders through the taps, at 9:00 AM and 9:00 PM, for zooplankton countings and analyses of chlorophyll $a$ and particulate organic carbon (POC).

Microcrustaceans and Chaoborus larvae were fully counted in the samples on a stereomicroscope. Calculations were made of the depth of average densities (DAD) of each species using the formula of Worthington (1931), corrected by Pennak (1943):

Depth of average density $=\frac{x^{1} d^{1}+x^{2} d^{2}+\ldots}{x^{1}+x^{2}+\ldots}$

where $\mathrm{x}^{1}, \mathrm{x}^{2} \ldots=$ number of individuals in each sample and $\mathrm{d}^{1}, \mathrm{~d}^{2} \ldots=$ depth of each sample.

Statistical tests ( $T$-test and Mann-Whitney) were applied for the analysis of data distribution in the water column, by day and night.

Dissolved oxygen (+ temperature), $\mathrm{pH}$, electrical conductivity were monitored in the cylinders, twice a day, using Yellow Springs Inc. equipment models 95, 60, 30 , respectively, and Licor 250 for light intensity. The sensors were gently lowered into the water, immediately after the observations were completed, so as to not disturb the distribution of the organisms.

Chlorophyll $a$ and POC were analysed by the methods of Lorenzen (1967) and Strickland and Parsons (1972), respectively. 
Experiment I

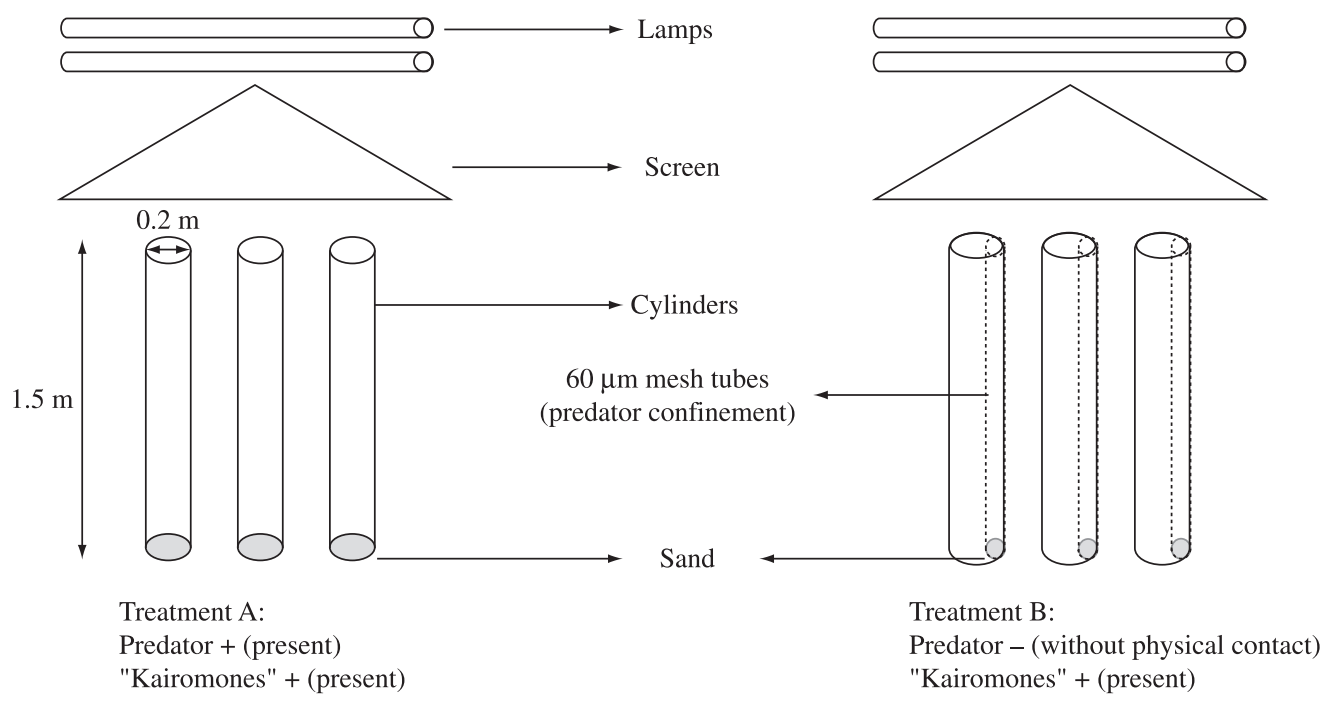

Experiment II
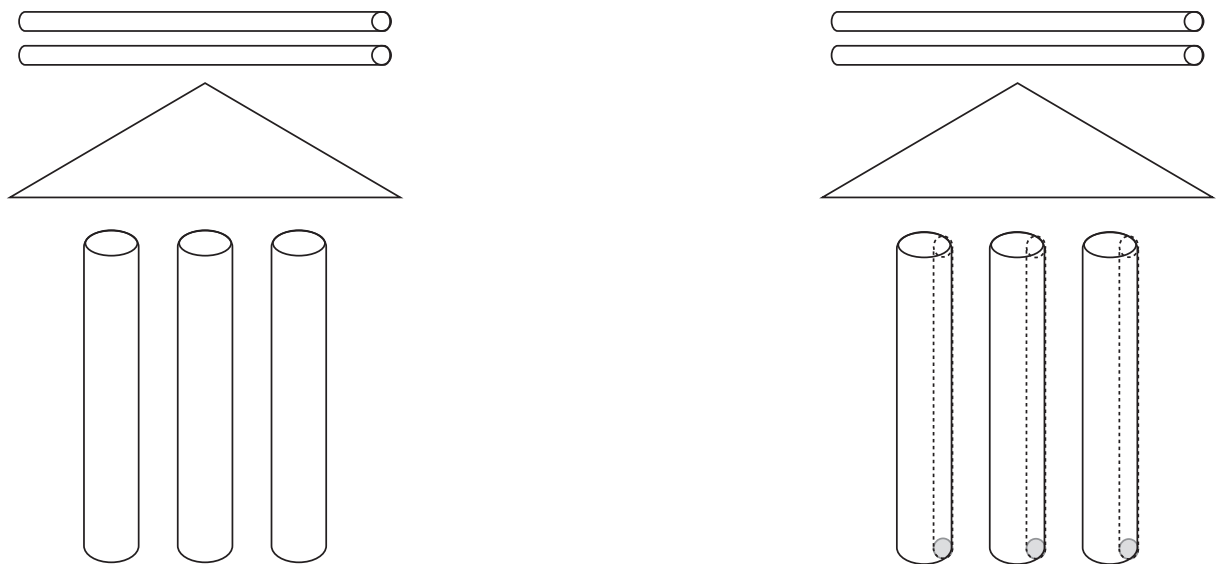

Treatment A:

Predator a (absent)

"Kairomones" - (absent)

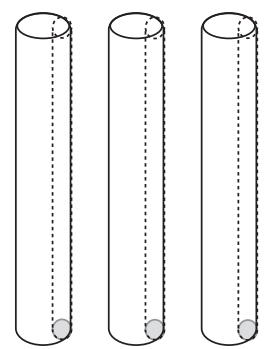

Treatment B:

Predator - (without physical contact)

"Kairomones" + (present)

Figure 1. Diagram of treatments A and B of Experiments I and II.

\section{Results}

\subsection{Physical, chemical and biological factors}

During the short periods water was taken for preparing the experiments, the lake was circulating and the temperature was around $20-21^{\circ} \mathrm{C}$ and dissolved oxygen ranged from 5 to $9 \mathrm{mg} . \mathrm{L}^{-1}$ in the water column.

The water column in all the replicates was not stratified in both experiments, temperature and dissolved oxygen varying from 23 to $24{ }^{\circ} \mathrm{C}$ and 6 to $7 \mathrm{mg} . \mathrm{L}^{-1}$, respectively. This condition was also indicated by the homogeneous vertical distribution of electrical conductivity and $\mathrm{pH}$. Attenuation of light occurred inside the tubes, simulating the lake condition (Figure 2).
Chlorophyll $a$ concentrations were evenly distributed in the cylinders, during the day and at night, lower values occurring in the latter period (Figure 3 ).

POC concentrations were close to values found in the lake during water samplings for both experiments (Table 1).

\subsection{DVM of predator and prey}

\subsubsection{Chaoborus brasiliensis}

In the treatment A of Experiment I, instars III and IV did not migrate, instar III being distributed in the water column, with higher densities near the bottom mainly at night, and IV concentrated near the bottom by day and 
Experiment I
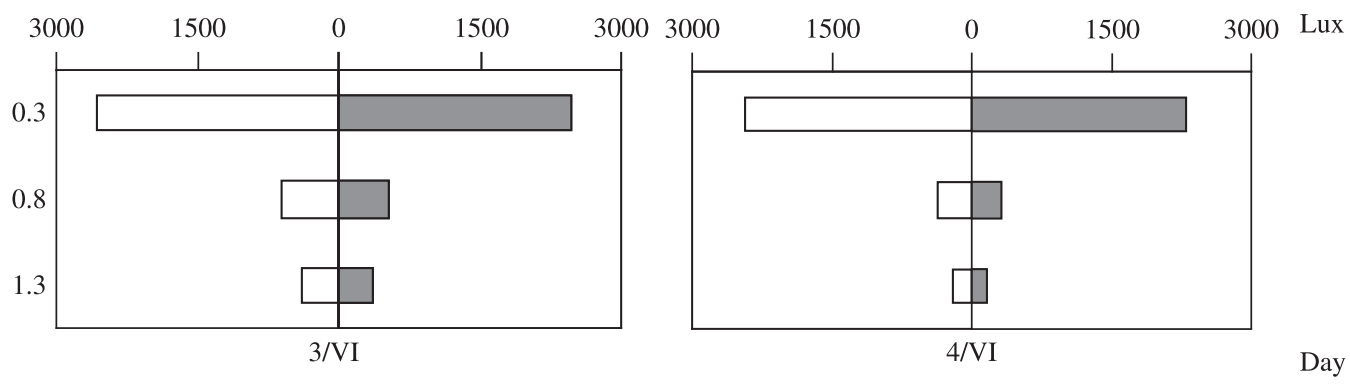

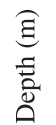

Experiment II

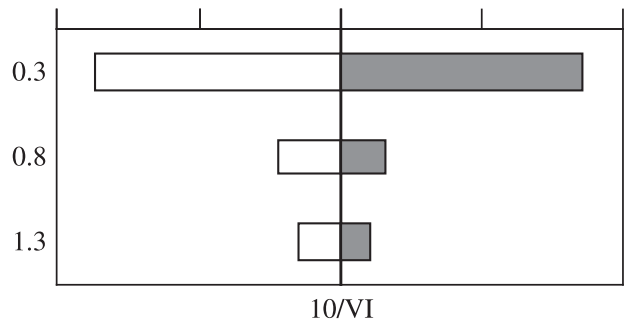

Treatment A

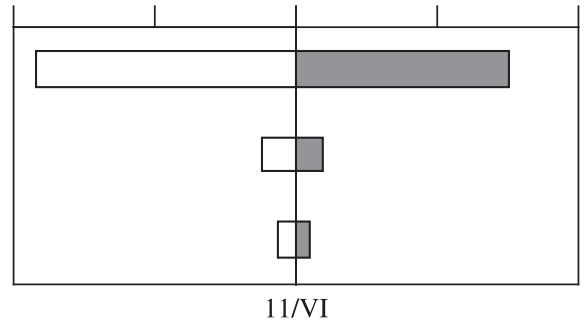

Treatment B

Figure 2. Average values of light intensity in the water column of treatments A and B of the experiments.

Experiment I

$\mathrm{P}+\mathrm{K}+$

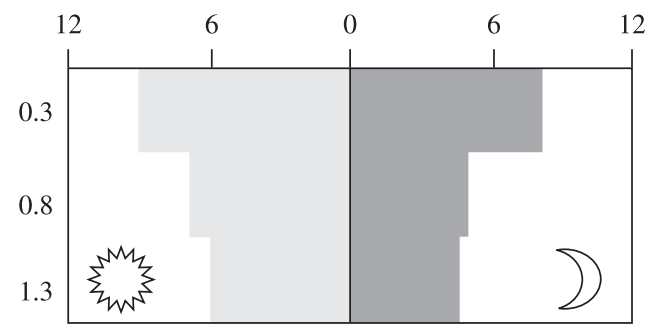

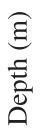

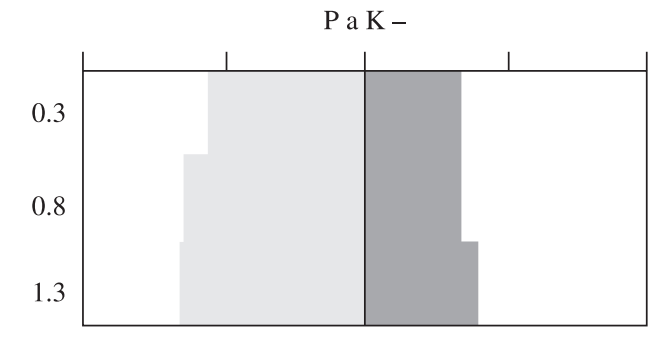

Treatment A
$12 \quad 12$

$\mathrm{P}-\mathrm{K}+$

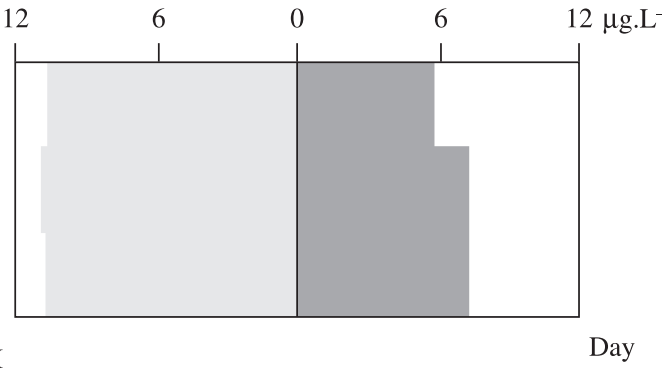

4/VI

Experiment II

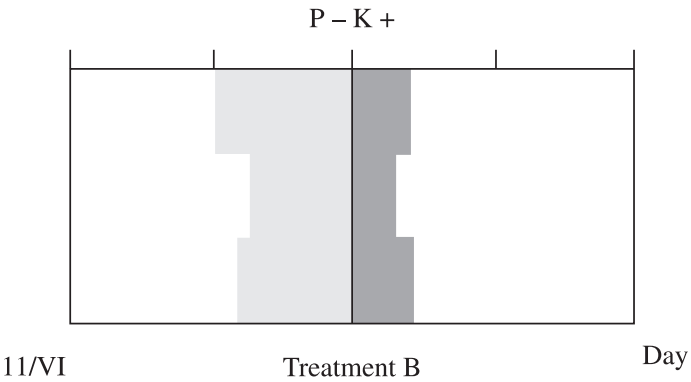

Figure 3. Average values of chlorophyll a in treatments A and B of the experiments, by day and night. 
Table 1. Average concentrations (+ SD) of Particulate Organic Carbon (POC) in both experiments and in the environment.

\begin{tabular}{ccc}
\hline & Experiment I & \\
\hline Date & Treatment & POC $\left(\mathbf{m g C . L}^{\mathbf{- 1}}\right)$ \\
\hline $31 / \mathrm{V} / 2004$ & Environment & $0.85 \pm 0.01$ \\
$4 / \mathrm{VI} / 2004$ & $\mathrm{~A}$ & $0.80 \pm 0.38$ \\
$4 / \mathrm{VI} / 2004$ & $\mathrm{~B}$ & $0.77 \pm 0.20$ \\
\hline & Experiment II & $0.47 \pm 0.08$ \\
\hline 7/VI/2004 & Environment & $0.43 \pm 0.41$ \\
$11 / \mathrm{VI} / 2004$ & $\mathrm{~A}$ & $0.53 \pm 0.24$
\end{tabular}

Treatment A
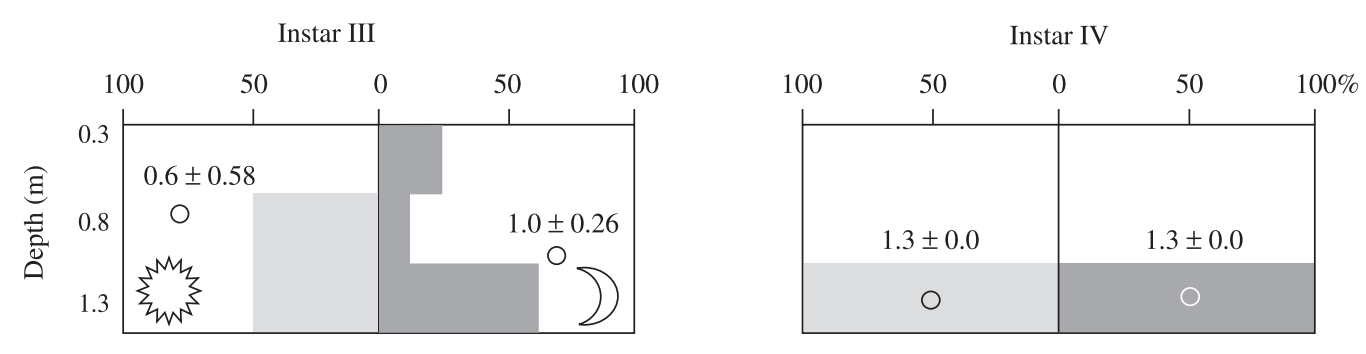

$\mathrm{P}+\mathrm{K}+$

Figure 4. Percentage of the average densities of instars III and IV of Chaoborus brasiliensis in treatment A of Experiment I, by day and night. Values inside the figure are the depth of the average density.

night (Figure 4). Instar II did not migrate either, being distributed in the water column.

Due to technical difficulties, the larvae displacement inside the net tubes of treatment B was not evaluated. At the end of the experiment the net tubes were emptied and larvae III and IV captured.

\subsubsection{Copepods and cladocerans}

Copepodites were distributed in the whole water column of the cylinders, during the day and at night, in treatments A and B of both experiments (Figures 5 and 6).

Like copepodites, adults of Tropocyclops prasinus and Thermocyclops decipiens occupied the water column in the cylinders of treatment A of Experiment I (Figure 5). In treatment $B$ of the same experiment, a significant difference $(p=0.1)$ between depth of the average density (DAD) at 9:00 AM and 9:00 PM was observed, the pattern being a reverse DVM.

In treatment A of Experiment II, adults of both copepods did not migrate, being distributed in the water column (Figure 6). In treatment B, however, both copepods showed a reverse pattern, with a significant difference ( $\mathrm{p}=0.007$ and $\mathrm{p}=0.027$ for $T$. prasinus and T. decipiens, respectively) between DAD at 9:00 AM and 9:00 PM.

In treatment A of Experiment I, Daphnia gessneri showed a nocturnal pattern, with a significant difference between DAD at 9:00 AM and 9:00 PM ( $p=0.047)$
(Figure 7). In the other treatments of both experiments, the pattern was undefined, individuals being distributed in higher densities near the surface and the bottom.

\section{Discussion}

Higher concentrations of chlorophyll $a$ at daytime could be explained by the addition of $0.2 \mathrm{mg} \mathrm{C.L}{ }^{-1}$ of the green algae $S$. spinosus to the cylinders, in early morning, a few hours before water sampling. Phytoplankton loss by sedimentation and grazing by zooplankton might be the reasons for lower chlorophyll concentrations at night. Chlorophyll $a$ vertical distribution and POC values in the treatments of both experiments indicate that food was not an important factor influencing DVM. The fact that stratification was not established inside the cylinders also excludes the effect of temperature and oxygen distribution on the vertical displacement of the organisms.

A possible explanation for the absence of vertical migration by copepodites of the two copepod species, in both experiments, is that their predators, which are the larvae II (Perticarrari et al., 2004), showed an undefined DVM pattern. Therefore, there was no parameter for copepodites to move in the water column for avoiding predation, which, on the other hand, is low at this stage in the lake. In treatment A of Experiment II, the absence of larvae and kairomones could be the reason for the lack of reaction of the individuals to the variation 


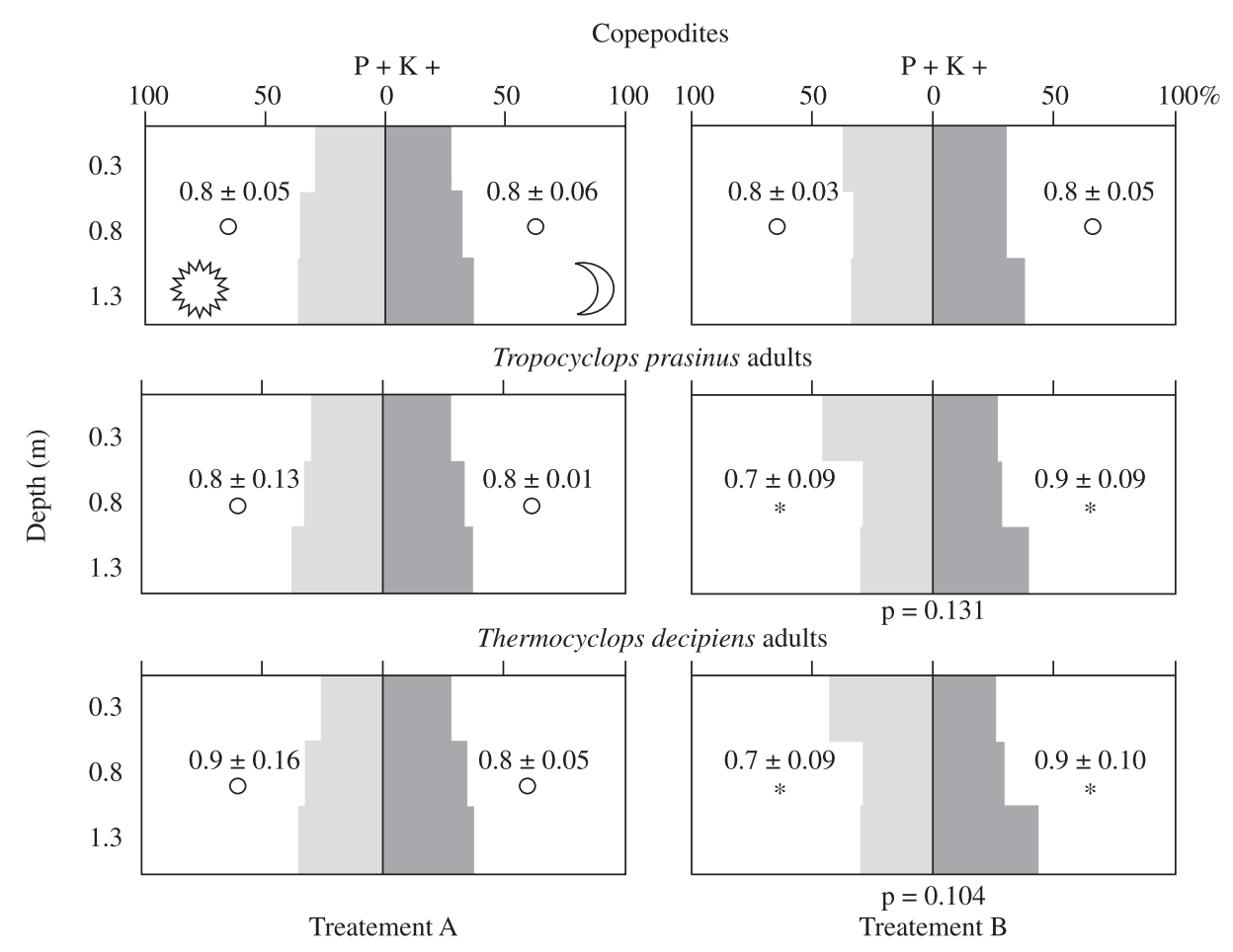

Figure 5. Percentage of the average densities of copepodites and adults of Tropocyclops prasinus meridionalis and Thermocyclops decipiens, in treatments $\mathrm{A}(\mathrm{P}+\mathrm{K}+)$ and $\mathrm{B}(\mathrm{P}-\mathrm{K}+)$ of Experiment $\mathrm{I}$. Values inside the figure are of the depth of the average density (average values $+\mathrm{SD}$ ). $\mathrm{P}=$ predator and $\mathrm{K}=$ kairomones; $*$ significant value at $\mathrm{p}=0.1$.

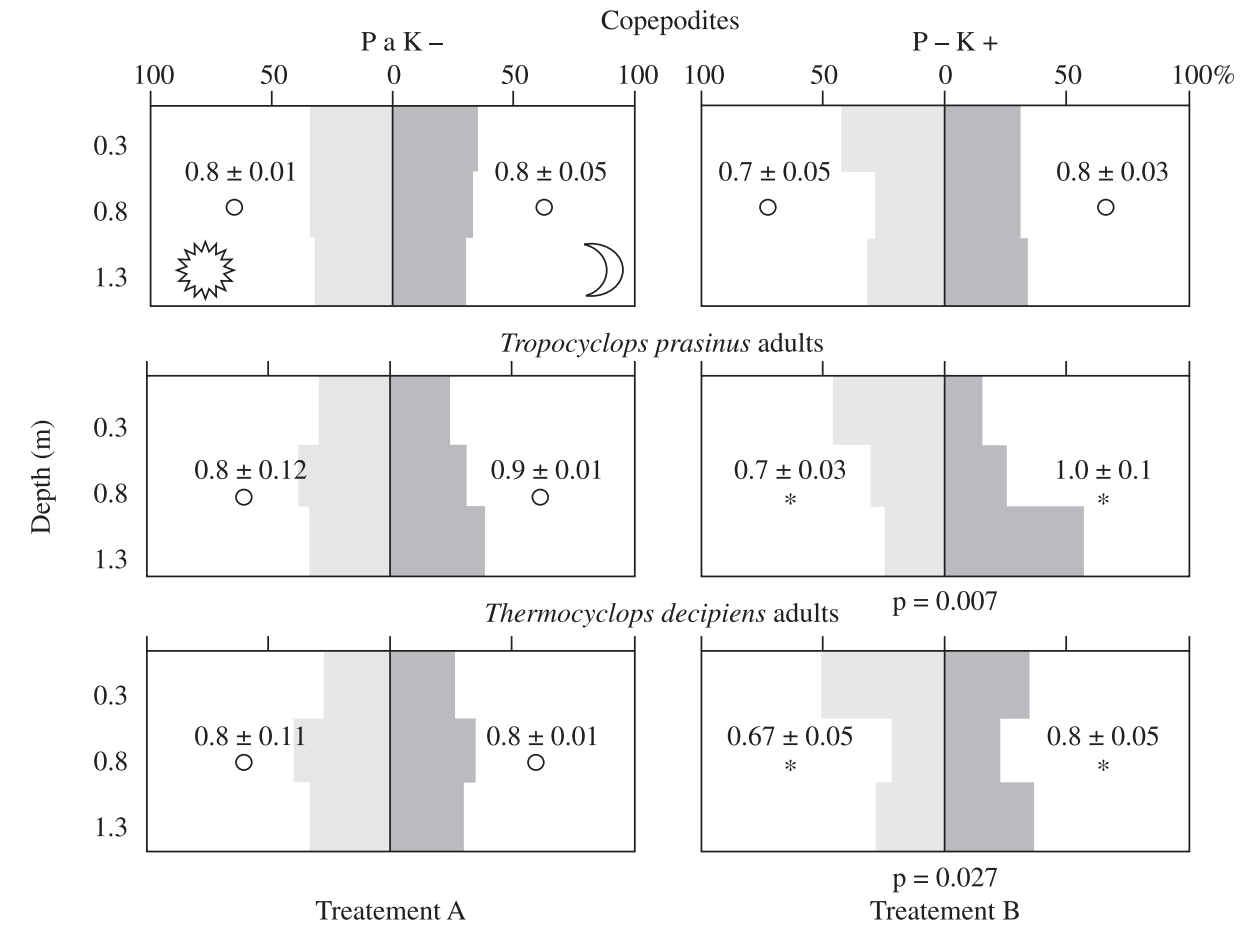

Figura 6. Percentage of the average densities of copepodites and adults of Tropocyclops prasinus meridionalis and Thermocyclops decipiens, in treatments $\mathrm{A}(\mathrm{Pa} \mathrm{K}-)$ and $\mathrm{B}(\mathrm{P}-\mathrm{K}+)$ of Experiment II. Values inside the figure are the depth of the average density (averages $+\mathrm{SD}) . \mathrm{P}=$ predator, $\mathrm{Pa}=$ predator totally absent, and $\mathrm{K}=$ kairomones; $*$ significant value at $\mathrm{p}=0.1$. 


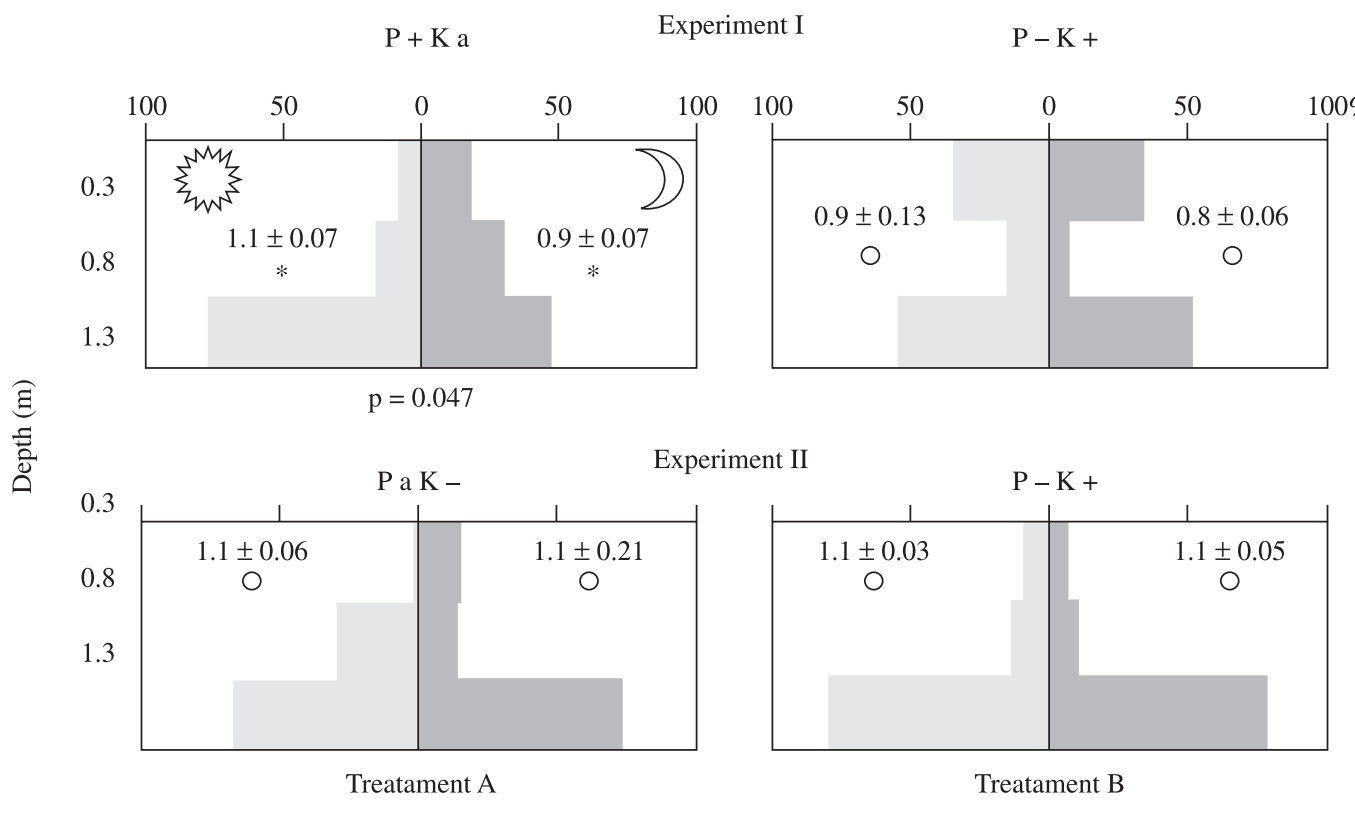

Figure 7. Percentage of the average densities of Daphnia gessneri in treatments $\mathrm{A}(\mathrm{P}+\mathrm{K}+)$ and $\mathrm{B}(\mathrm{P}-\mathrm{K}+)$ of Experiment $\mathrm{I}$ and treatments $\mathrm{A}(\mathrm{Pa} \mathrm{K}-)$ and $\mathrm{B}(\mathrm{P}-\mathrm{K}+)$ of Experiment II. Values inside the figure are the depth of the average density (averages $+\mathrm{SD}) . \mathrm{P}=$ predator, $\mathrm{Pa}=$ predator entirely absent, and $\mathrm{K}=$ kairomones; * significant value at $\mathrm{p}=0.1$.

of light intensity. Ohman (1990) reported that under low predation pressure by invertebrates, copepodites I to III did not migrate.

Adult copepods showed an undetectable pattern in conditions of physical contact with predators (treatment A of Experiment I) or the absence of predators and kairomones (treatment A of Experiment II). Larvae III and IV, the predators of copepods, were distributed, in treatment A of Experiment I, mostly in mid-water or near the bottom by day and night. The predator occupation of almost the entire column of the cylinders could be confusing for prey, whose reaction to light was precluded. In treatment A of Experiment II, the reason for lack of copepod DVM might be the absence of predators and kairomones. However, a reverse migration in treatment $\mathrm{B}$ of both experiments, when predators were confined in net tubes, was performed by adults of both copepod species. It is possible that the kairomones were signalising a defined DVM pattern of Chaoborus larvae. Copepods were sensitive to kairomones, not requiring a physical contact with predators, and reacted to light in a reverse pattern.

Several studies have indicated that reverse migration could be triggered by vertebrate and invertebrate predators, when they migrate in a nocturnal way. Most publications deal with fish as predators and fewer with invertebrate predators (Ohman et al., 1983; Neill, 1990, 1992; Ohman, 1990). The lower overlap resulting from distinct occupation of the water column by predator and prey could represent a significant decrease in predation, increasing prey survival and population success. Prey re- verse migration can be an indirect reaction to visual predation by fish, as invertebrate predators may escape from fish predation descending to deeper layers at daytime, ascending to upper layers for feeding at night (review by Lampert, 1993).

The response of prey to invertebrate predators can be quick ( $<4$ hours) as shown by Neill (1990) in experiments. The introduction of Chaoborus trivittatus in enclosures resulted in reverse migration by the copepod Diaptomus kenai, which did not migrate in the absence of the predator. Reverse migration was also observed after water with kairomones was introduced in the enclosures. These findings show that copepods are sensitive to substances liberated by predators. Less than 7 hours after their introduction in enclosures, larvae of Chaoborus flavicans and C. trivittatus induced DVM by copepodites of D. kenai (Neill, 1992).

The marine copepod Pseudocalanus sp. reverse migrated when the predators, the cheatognath Sagitta elegans and the copepod Euchaeta elongata were present and nocturnally migrated (Ohman et al., 1983). A small reduction of mortality rate $(16 \%)$ was advantageous for prey population, compensating the demographic disadvantage in daily migratory displacements within a thermal gradient. The population of the copepod Pseudocalanus newmani exhibited three migratory behaviours according to predation pressure (Ohman, 1990): nocturnal under higher predation by visual planktivorous fish; reverse when invertebrate predation was stronger; non-migrating when predation pressure was low. 
After the disappearance of Chaoborus' favourite cladoceran prey, Bosmina tubicen (Arcifa, 2000), a change of copepod DVM was detected in Lake Monte Alegre (Perticarrari et al., 2004). The twilight pattern was replaced by the reverse one, interpreted by the authors as a response of copepods to the increase in predation pressure. Both species of copepods, Tropocyclops prasinus and Thermocyclops decipiens, responded similarly to increasing predation. A deterrent to copepod reverse migration was the lake stratification, which leads to low oxygen concentrations in the narrow hypolimnion, precluding the occupation of the whole water column by the individuals.

Physical contact with the predator seems to be important for the Daphnia gessneri population reacting and performing a nocturnal DVM, as occurred in treatment A of Experiment I. Lack of migratory behaviour in treatment B of both experiments might indicate that kairomones alone do not have the same effect on Daphnia.

Instar IV was the main predator of Daphnia gessneri in Lake Monte Alegre, when Bosmina was the favourite prey of Chaoborus larvae (Arcifa, 2000), or later when copepods were more preyed on by larvae (Perticarrari et al., 2004). Larvae IV did not migrate in experiment I, remaining preferentially near the bottom by day and night. The larvae select young $D$. gessneri in relation to adults (Castilho-Noll and Arcifa, 2007a), which can be more superficially located in the lake, resulting in a lower spatial overlap with Chaoborus (Sousa, 2003). This ontogenetic behavioural difference could explain the movement of part of the population in the present experiments. D. gessneri never performed reverse migration in the lake, showing a trend for nocturnal pattern in several DVM studies made in the lake (Perticarrari et al., 2003). Aggregates of Daphnia were interpreted by the authors as an escape reaction to invertebrate predators, represented in 1999 and 2001 by Chaoborus larvae and water mites. The adaptive value of the reverse migration in the lake is doubtful for the cladoceran as the population would be more vulnerable to predation by adult tilapia, a pump-filter feeder that selects Daphnia but not copepods, only during the day as it is a diurnal fish (Arcifa and Meschiatti, 1996).

Other studies, however, showed that the vertical migration of Daphnia can be stimulated by kairomones, responding differentially to kairomones of fishes and invertebrates (Lass et al., 2001). As observed for copepods, Daphnia magna can react to kairomones in a few hours (De Meester and Cousyn, 1997). However, kairomones can exert an influence on DVM when associated to light intensity variation. Loose (1993) showed in experiments that a dark/light cycle was necessary for Daphnia galeata and D. hyalina to react to kairomones of fishes and perform nocturnal migration. Besides light intensity variation being fundamental for kairomones to act as a stimulus for migration, there is a threshold concentration of kairomones to induce the movement (Ringelberg, 1991b).
An important observation is that the DVM of the microcrustaceans in the experiments was performed as an asynchronous movement of the individuals of the populations, which was magnified in the cylinders due to their low height. The same fact has been reported in most studies on DVM in the field, including those of Lake Monte Alegre (Perticarrari et al., 2003; 2004).

\section{Conclusions}

Larvae of Chaoborus brasiliensis may induce the reaction of the cladoceran Daphnia gessneri and the copepods Thermocyclops decipiens and Tropocyclops prasinus meridionalis to light intensity variation, leading them to migrate. Daphnia gessneri responded to the physical contact with the predator migrating nocturnally but was unresponsive to kairomones alone. The copepods were sensitive to kairomones adopting a reverse DVM pattern, but the physical contact with predator, which occupied most of the water column, seemed to confuse prey and to preclude its reaction to light.

Acknowledgements - We thank the laboratory team Claudia Fileto, Maria S. M. Castilho-Noll, Adriana J. Meschiatti, Mara A. Marçal-Simabuku, and André L. H. Esguícero for help on several occasions. We also thank João A. Jorge and Maurício de Oliveira for the loan of equipment, Reginaldo C. dos Santos for the statistical assistance, and an anonymous referee for valuable suggestions. Thanks are also due to the Graduate Program in Comparative Biology for financial support and CAPES for a grant to W.J.M.

\section{References}

ARCIFA, MS., 2000. Feeding habits of Chaoboridae larvae in a tropical Brazilian reservoir. Revista Brasileira de Biologia $=$ Brazilian Journal of Biology, vol. 60, no. 4, p. 591-597.

ARCIFA, MS., MESCHIATTI, AJ. and GOMES, EAT., 1990. Thermal regime and stability of a tropical shallow reservoir: Lake Monte Alegre, Brazil. Revue d'Hydrobiologie tropicale, vol. 23 , no. 4 , p. 271-281.

ARCIFA, MS., GOMES, EAT. and MESCHIATTI, AJ., 1992. Composition and fluctuations of the zooplankton of a tropical Brazilian reservoir. Archiv für Hydrobiologie, vol. 123, no. 4, p. $479-495$.

ARCIFA, MS. and MESCHIATTI, AJ., 1993. Distribution and feeding ecology of fishes in a Brazilian reservoir: Lake Monte Alegre. Interciencia, vol. 18, no. 6, p. 302-313.

, 1996. Tilapia rendalli in the Lake Monte Alegre, a case of planktivory. Acta Limnologica Brasiliensia, vol. 8, no. 1, p. 221-229.

ARCIFA, MS., SILVA, LHS. and SILVA, MHL., 1998. The planktonic community in a tropical Brazilian reservoir: composition, fluctuations and interactions. Revista Brasileira de Biologia = Brazilian Journal of Biology, vol. 58, no. 2, p. 241-254.

BOLLENS, SM. and FROST, BW., 1991. Diel vertical migration in zooplankton: rapid individual response to predators. Journal of Plankton Research, vol. 13, no.6, p. 1359-1365. 
BUNIOTO, TC., 2003. Variação temporal e distribuição horizontal do zooplâncton no Lago Monte Alegre e a influência do alimento e da temperatura sobre cladóceros. Ribeirão Preto: Universidade de São Paulo. 96 p. [Dissertação de Mestrado]

CASSANO, CR., CASTILHO-NOLL, MSM. and ARCIFA, MS., 2002. Water mite predation on zooplankton of a tropical lake. Revista Brasileira de Biologia = Brazilian Journal of Biology, vol. 62, no. 4A, p. 565-571.

CASTILHO-NOLL, MSM. and ARCIFA, MS., 2007a. Chaoborus diet in a tropical lake and predation of microcrustaceans in laboratory experiments. Acta Limnologica Brasiliensia, vol. 19, no. 2, p. 163-174.

2007b. Mesocosm experiment on the impact of invertebrate predation on zooplankton of a tropical lake. Aquatic Ecology, vol. 41, no. 4, p. 587-598.

DAWIDOWICZ, P., PIJANOWSKA, J. and CIECHOMSKI, K. 1990. Vertical migration of Chaoborus larvae is induced by the presence of fish. Limnology and Oceanography, vol. 35, no. 7, p. 1631-1637.

DINI, ML. and CARPENTER, SR., 1988. Variability in Daphnia behavior following fish Community manipulation. Journal of Plankton Research, vol. 10, no. 4, p. 621-635.

1991. The effect of whole-lake fish community manipulations on Daphnia migratory behavior. Limnology and Oceanography, vol. 36, no. 2, p. 370-377.

Von ELERT, E. and POHNERT, G. 2000. Predator specificity of kairomones in diel vertical migration of Daphnia: a chemical approach. Oikos, vol. 88, p. 119-128.

FILETO, C. 2001. O zooplâncton do Lago Monte Alegre: variação temporal e a influência das frações do fitoplâncton sobre o crescimento e reprodução de cladóceros. Ribeirão Preto: Universidade de São Paulo. 100 p. [Dissertação de Mestrado].

GLIWICZ, MZ., 1986. Predation and the evolution of vertical migration in zooplankton. Nature, vol. 320, p. 746-748.

HUTCHINSON, GE., 1967. A Treatise on Limnology. II. Introduction to Lake Biology and the Limnoplankton. New York: John Wiley and Sons. $1115 \mathrm{p}$.

JOHNSEN, GH. and JAKOBSEN, PJ., 1987. The effect of food limitation on vertical migration in Daphnia longispina. Limnology and Oceanography, vol. 32, no. 4, p. 873-880.

LAMPERT, W. 1993. Utimate causes of diel vertical migration of zooplankton: new evidence for the predator-avoidance hypothesis. Archiv für Hydrobiologie/Beiheft Ergebnisse der Limnologie, vol. 39, p. 79-88.

LAMPERT, W. and TAYLOR, BE., 1985. Zooplankton grazing in a eutrophic lake: implications of diel vertical migration. Ecology, vol. 66, no. 1, p. 68-82.

LARSSON,P. andDODSON, S., 1993. Chemical communication in planktonic animals. Archiv für Hydrobiologie, vol. 129, p. $129-155$.

LASS, L., BOERSMA, M., WILTSHIRE, KH., SPAAK, P. and BORISS, H., 2001. Does trimethylamine induce life-history in Daphnia? Hydrobiologia, vol. 442, no. 1-3, p. 199-206.

LASS, S. and SPAAK, P., 2003. Chemically induced anti-predator defences in plankton: a review. Archiv für Hydrobiologie, vol. 491, p. 221-239.
LOOSE, CJ., 1993. Daphnia diel vertical migration behavior: response to vertebrate predator abundance. Archiv für Hydrobiologie/Beiheft Ergebnisse der Limnologie, vol. 39, p. 29-36.

LOOSE, CJ., Von ELERT, E. and DAWIDOWICZ, P., 1993. Chemically-induced diel vertical migration in Daphnia: a new biassay for kairomones exuded by fish. Archiv für Hydrobiologie, vol. 126, p. 329-337.

LORENZEN, CJ., 1967. Determination of chlorophyll and pheopigments: spectro-photometric equations. Limnology and Oceanography, vol. 12, no. 2, p. 343-346.

MEESTER, L. and COUSYN, C., 1997. The change in phototatic behaviour of a Daphnia magna clone in the presence of fish kairomones: the effect of exposure time. Hydrobiologia, vol. 360, no. 1-3, p. 169-175.

MESCHIATTI, AJ. and ARCIFA, MS., 2002. Early life stages of fish and the relationships with zooplankton in a tropical Brazilian reservoir: Lake Monte Alegre. Revista Brasileira de Biologia $=$ Brazilian Journal of Biology, vol. 62, no. 1, p. 41-50.

NEILL, WE., 1990. Induced vertical migration in copepods as a defense against invertebrate predation. Nature, vol. 345, p. 524-525.

1992. Population variation in the ontogeny of predator-induced vertical migration of copepods. Nature, vol. 356, p. 54-57.

OHMAN, MD., 1990. The demographic benefits of diel vertical migration by zooplankton. Ecological Monographs, vol. 60, no. 3, p. 257-281.

OHMAN, MD., FROST, BW. and COHEN, EB., 1983. Reverse diel vertical migration: an escape from invertebrate predators. Science, vol. 220, no. 4604, p. 1404-1407.

PENNAK, RW., 1943. An effective method of diagramming diurnal movements of zooplankton organisms. Ecology, vol. 24, no. 3 , p. 405-407.

PERTICARRARI, A., ARCIFA, MS. and RODRIGUES, RA., 2003. Diel vertical migration of cladocerans in a tropical lake. Nauplius, vol. 11, no. 1, p. 15-25.

2004. Diel vertical migration of copepods in a Brazilian lake: a mechanism for decreasing risk of Chaoborus predation? Revista Brasileira de Biologia = Brazilian Journal of Biology, vol. 64 , no. 2, p. 289-298.

RINGELBERG, J., 1980. Introductory remarks: causal and teleological aspects of diurnal vertical migration. In KERFOOT, WC. (Ed.). Evolution and ecology of zooplankton communities. Hanover: University Press of New England. p. 65-68.

1991a. The relation between ultimate and proximate aspects of diel vertical migration in Daphnia hyalina. Verhandlungen der Internationale Vereinigung der Limnologie, vol. 24 , no. 5, p. 2804-2807.

1991b. A mechanism of predator-mediated induction of diel vertical migration in Daphnia hyalina. Journal of Plankton Research, vol. 13, no. 1, p. 83-89.

1991c. Enhancement of the phototactic reaction in Daphnia hyalina by a chemical mediated by juvenile perch (Perca fluviatilis). Journal of Plankton Research, vol. 13, no. 1, p. $17-25$. 
1993. Phototaxis as a behavioral component of diel vertical migration in a pelagic Daphnia. Archiv für Hydrobiologie/Beiheft Ergebnisse der Limnologie, vol. 39, p. $45-55$.

RINGELBERG, J., FLIK, BJ., LINDENAAR, D. and ROYACKERS, K. 1991. Diel vertical migration of Daphnia hyalina (sensulatiori) in Lake Maarssenveen. Part 1: Aspects of seasonal and daily timing. Archiv für Hydrobiologie, vol. 121, p. $129-145$.

SOUSA, MP. 2003. Migração vertical de jovens e adultos dos cladóceros Daphnia ambigua e D. gessneri no Lago Monte Alegre. Ribeirão Preto: Universidade de São Paulo. 51 p. [Monografia].

STICH, HB. and LAMPERT, W. 1981. Predation evasion as an explanation of diurnal vertical migration by zooplankton. Nature, vol. 293, p. 396-398.
STRICKLAND, JDH. and PARSONS, TR. 1972. A pratical handbook of seawater analysis. 2 ed. Canada: Fisheries Research Board of Canada. 310 p. (Bulletin no. 167).

TJOSSEM, SF. 1990. Effect of fish chemical cues on vertical migration behavior of Chaoborus. Limnology and Oceanography, vol. 35, no. 7, p. 1456-1468.

WORTHINGTON, EB. 1931. Vertical movements of fresh-water macroplankton. Internationale Revue der gesammte Hydrobiologie, vol. 25, no. 5-6, p. 394-436.

WRIGHT, D., O'BRIEN, WJ. and VINYARD, GL. 1980. Adaptive value of vertical migration: a simulation model argument for the predation hypothesis. In KERFOOT, WC. (Ed.). Evolution and Ecology of Zooplankton Communities. Hanover: University Press of New England. p. 138-147.

ZARET, TM. and SUFFERN, JS. 1976. Vertical migration in zooplankton as a predator avoidance mechanism. Limnology and Oceanography, vol. 21, no. 6, p. 804-813. 